\title{
Pandemic influenza A(H1N1)2009 in Morocco: experience of the Mohammed V Military Teaching Hospital, Rabat, 12 June to 24 December 2009
}

I Lahlou Amine (idr_lahlou@yahoo.com) ${ }^{1}$, T Bajjou ${ }^{1}$, H El Rhaffouli ${ }^{1}$, A Laraqui $^{1}$, F Hilali $^{1}$, K Menouar $^{1}$, K Ennibi $^{2}$, M Boudlal $^{2}$, E A Bouaiti', K Sbai ${ }^{3}$, M Rbai $^{3}$, M Hachim², S Zouhair ${ }^{1}$

1. University Mohammed V-Souissi, Faculty of Medicine and Pharmacy, Mohammed V Military Teaching Hospital, Biosafety Level 3 and Research Laboratory, Rabat, Morocco

2. University Mohammed V-Souissi, Faculty of Medicine and Pharmacy, Mohammed V Military Teaching Hospital, Department of Internal Medicine, Rabat, Morocco

3. Royal Armed Forces' Health Services, Division for Health and Safety Surveillance, Rabat, Morocco

Citation style for this article:

Lahlou Amine I, Bajjou T, El Rhaffouli H, Laraqui A, Hilali F, Menouar K, Ennibi K, Boudlal M, Bouaiti EA, Sbai K, Rbai M, Hachim M, Zouhair S. Pandemic influenza

$\mathrm{A}\left(\mathrm{H}_{1} \mathrm{~N}_{1}\right) 2009$ in Morocco: experience of the Mohammed V Military Teaching Hospital, Rabat, 12 June to 24 December 2009. Euro Surveill. $2011 ; 16(23)$ : pii=19885

Euro Surveill. 2011;16(23):pii=19887. Available online: http://www.eurosurveillance.org/ViewArticle.aspx?Articleld=19887

On 12 June 2009, Morocco was the first country in North Africa to report a laboratory-confirmed case of influenza $A\left(\mathrm{H}_{1} \mathrm{~N}_{1}\right)_{2009}$ virus infection. This study describes the epidemiological and clinical characteristics of 240 laboratory-confirmed cases among 594 outpatients with influenza-like illness at the Mohammed V Military Teaching Hospital, Rabat, from 12 June to 24 December 2009. Real-time reverse transcriptionPCR was used to confirm the infection. The epidemic peaked in weeks 47 to 49 (16 November to 6 December 2009). The mean age of cases was 23 years (standard deviation: 14 years). Cough was the most common symptom in 200 cases ( $83 \%)$, followed by fever $\left(\geq 38^{\circ} \mathrm{C}\right)$ in $195(81 \%)$. Diarrhoea or vomiting was reported in 12 ( $5 \%)$ patients. None of the cases developed any complications and no deaths occurred during the study period.

\section{Introduction}

Following its identification in humans in Mexico and in the United States in April 2009 [1], the pandemic influenza $A\left(\mathrm{H}_{1} \mathrm{~N}_{1}\right) 2009$ virus spread worldwide [2]. On 11 June 2009, the World Health Organization (WHO) raised the pandemic alert level from phase 5 to phase 6 , officially marking the beginning of the 2009 influenza pandemic [3]. On 12 June 2009, the Division of Epidemiology and Disease Control of the Moroccan Ministry of Health reported the first laboratory-confirmed case of influenza $A\left(\mathrm{H}_{1} \mathrm{~N}_{1}\right) 2009$ virus infection in north Africa, in a traveller returning from Canada [4]. Subsequently, the number of laboratory confirmed cases in Morocco rose continuously, and reached a total of 2,890 including 64 deaths by 10 March 2010 [5].

The burden of influenza on the African continent is unclear. This is in part due to a lack of systematic surveillance across the continent, limited testing facilities and the prioritisation of other infectious diseases.
Factors, such as health care availability, prevalence of co-morbidities or co-infections, or population age structure could affect the influenza burden specifically for this continent. Data from Africa on the pandemic influenza $A\left(\mathrm{H}_{1} \mathrm{~N}_{1}\right)_{2009}$ is also scarce $[6,7]$. A comprehensive surveillance from all parts of the world is nevertheless important.

The aim of this study, performed in the Mohammed $\mathrm{V}$ Military Teaching Hospital (MVMTH) in Rabat, Morocco, was to investigate the epidemiological and clinical characteristics of the cases of influenza $A\left(\mathrm{H}_{1} \mathrm{~N}_{1}\right)_{2009}$ and to report the laboratory diagnosis data in our hospital during the pandemic from June 2009 to December 2009.

The MVMTH in Rabat, Morocco, is a 1,000 bed university hospital with about 80,000 inpatient admissions and 200,000 outpatients per year. It is intended for active or retired military personnel as well as their families in priority, but it also treats civilians thereby serving about 5 million people living in the north of the country. At the time the pandemic began (12 June 2009), the MVMTH was opened to all the population for influenza diagnosis and treatment. This resulted in a small, yet insignificant, increase in out- and inpatients at the hospital.

\section{Methods}

\section{Patients and samples}

The study, conducted from 12 June to 24 December 2009, involved 594 outpatients with influenza-like illness (ILI) characterised by at least two of the following symptoms including fever $\left(\geq 38{ }^{\circ} \mathrm{C}\right)$, cough, muscular pain, headache, rhinorrhoea, dyspnoea, diarrhoea and vomiting. Demographic, clinical and epidemiological data of patients were collected by the medical staff using a questionnaire that was completed when 
samples were taken. The items collected on the questionnaire were: age, sex, clinical symptoms, co-morbidities, recent travel history in an epidemic country and vaccination against seasonal influenza.

In the period from 12 June to 28 August (referred to as the pre-epidemic period for this study), in which all the confirmed cases of $\mathrm{A}\left(\mathrm{H}_{1} \mathrm{~N}_{1}\right)_{2009}$ were imported, swabs were taken from ILI outpatients and a total of 18 of their contacts. During the period from 29 August to 24 December (here referred to as the epidemic period), in which there were also autochtonous cases with no travel history in an epidemic country, the collection of specimens was restricted to ILI outpatients and for grouped cases, such as members of the same family or of the same school class or cases in the same military barracks, only a representative sample was tested for influenza $A\left(\mathrm{H}_{1} \mathrm{~N}_{1}\right) 2009$ virus infection.

Oseltamivir was given to all patients immediately after sampling. The treatment was stopped if patients tested negative for influenza $A\left(\mathrm{H}_{1} \mathrm{~N}_{1}\right)_{2009}$. Patients who were confirmed positive for influenza $A\left(\mathrm{H}_{1} \mathrm{~N}_{1}\right) 2009$ continued the treatment (oseltamivir $2 \times 75 \mathrm{mg} /$ day for five days) and all their contacts received preventive treatment. The follow-up of patients was documented. At the beginning of the pandemic, a hospital ward with 20 beds was reserved for the treatment and quarantine of influenza patients. As the virulence of the strain was unknown, all suspected cases were maintained in quarantine until they were confirmed. For cases who were positive for influenza $A\left(\mathrm{H}_{1} \mathrm{~N}_{1}\right)_{2} 2009$, containment was maintained until they recovered. As ILI cases increased from mid-november, these measures were replaced by homecare.

\section{Laboratory confirmation of infection with influenza $\mathrm{A}(\mathrm{H} 1 \mathrm{N1}) 2009$ virus}

ILI patients were swabbed and nasopharyngeal swabs from the patients were transported to the biosafety level-3 laboratory in a standard, triple-packaging system following the United Nations (UN) 2814 class 6.2 specifications [8]. RNA was extracted from nasopharyngeal swabs using the High Pure Viral RNA Isolation Kit (Roche) and one-step real-time RT-PCR was performed using the RealTime ready Influenza $A / \mathrm{H}_{1} \mathrm{~N}_{1}$ Detection Set and RealTime ready RNA Virus Master (Roche). A confirmed case was defined as an ILI case whose

\section{FIGURE 1}

Patients with influenza-like illness and laboratory-confirmed cases of influenza A(H1N1)2009 virus infections, Mohammed V Military Teaching Hospital, Rabat, Morocco, 12 June-24 December 2009 ( $n=240)$

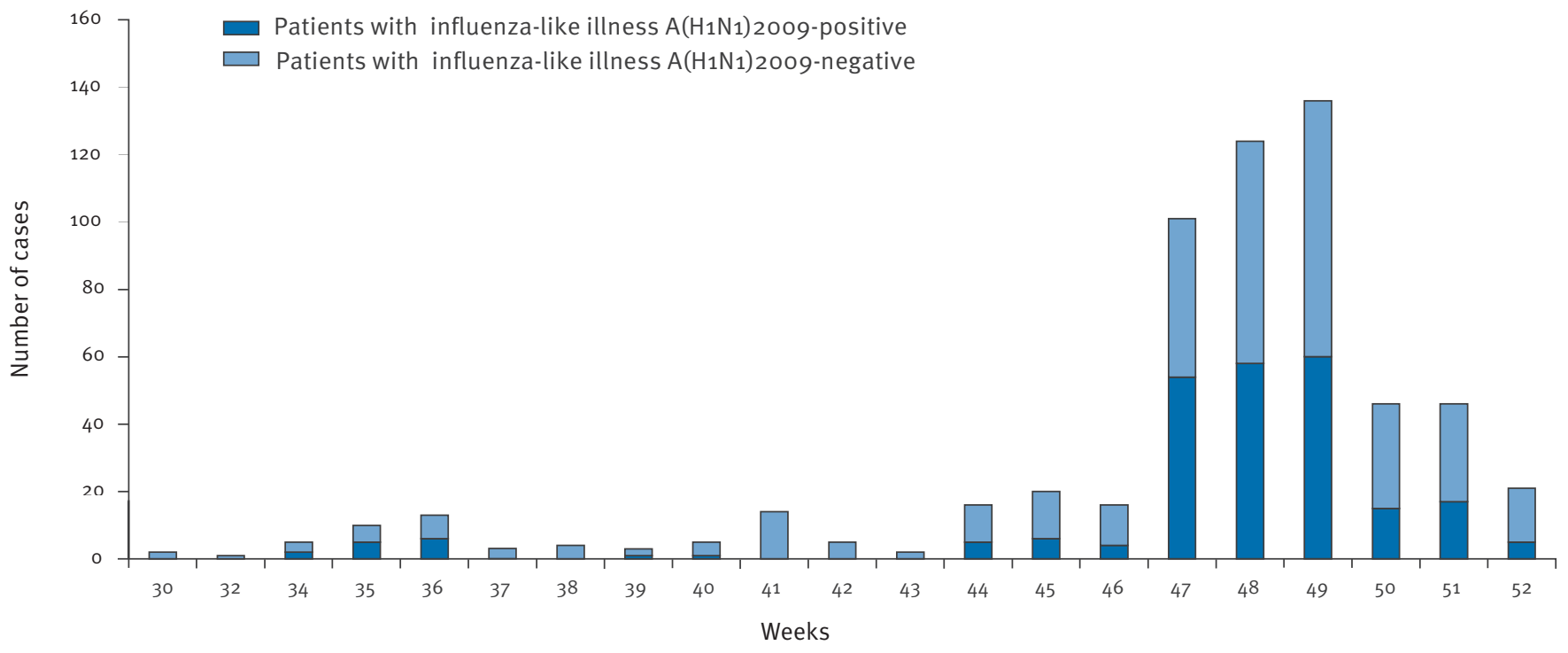

TABLE 1

Characteristics of patients with influenza-like illness and laboratory-confirmed cases of influenza A(H1N1)2009 virus infections, Mohammed V Military Teaching Hospital, Rabat, Morocco, 12 June-24 December 2009 (n=594)

\begin{tabular}{|l|c|c|c|}
\hline Characteristic & Total & $\begin{array}{c}\text { Patients with influenza-like } \\
\text { illness A(H1N1)2009-negative } \\
n(\%)\end{array}$ & $\begin{array}{c}\text { Patients with influenza-like } \\
\text { illness A(H1N1) 2009-positive } \\
n(\%)\end{array}$ \\
\hline Number of patients, N (\%) & $\mathbf{5 9 4}$ & $354(60 \%)$ & $\mathbf{2 4 0}(\mathbf{4 0 \% )}$ \\
\hline Number of males, n/N (\%) & $\mathbf{3 4 9 ( 5 9 \% )}$ & $\mathbf{2 0 0 / 3 5 4 ( 5 6 \% )}$ & $\mathbf{1 4 9 / 2 4 0 ( 6 2 \% )}$ \\
\hline $\begin{array}{l}\text { Mean Age and standard } \\
\text { deviation }\end{array}$ & $\mathbf{2 8 \pm 1 6}$ & $\mathbf{3 1 \pm 1 7}$ & $\mathbf{2 3 \pm 1 4}$ \\
\hline
\end{tabular}


swab yielded a positive RT-PCR result. Between 12 June and 28 August 2009, in the pre-epidemic phase, 18 contacts of confirmed cases, who did not necessarily present with ILI, were also tested for pandemic influenza $A\left(\mathrm{H}_{1} \mathrm{~N}_{1}\right)_{2009}$ virus infection using the same procedure as above. All the patients considered for this study were tested. We had two inhibited tests: they were repeated using different concentrations $(1 / 2,1 / 10$, $1 / 20$ ) and were both positive at the dilution of $1 / 10$.

\section{Statistical analysis}

All statistical analysis was carried out using SPSS (release 7.5.1). Normal data distributions were assessed with the Kolmogorov-Smirnov test. Skewed variables were natural log transformed. Patients' ages were categorised into six groups. Student's t-test and one-way analysis of variance procedures were used for the comparison of categorical variables between groups. Odds ratios (ORs) and 95\% confidence interval (CI) were obtained using the logistic regression model with backward likelihood ratio method. Removal testing is based on the probability of the likelihood-ratio statistic, which is also based on the maximum partial likelihood estimates. For this purpose, all variables were entered and eliminated step by step according to default criteria with a probability for entry and removal of 0.05 and 0.10 , respectively. Reference values were age greater than 40 years and an absence of symptoms for all clinical variables. A p value less than 0.05 was considered to be statistically significant.

\section{Results}

Of 594 ILI outpatients from 12 June to 24 December 2009, 240 (40\%) were laboratory confirmed as cases of influenza $\mathrm{A}\left(\mathrm{H}_{1} \mathrm{~N}_{1}\right)_{2009}$ virus infection and 354 (60\%) were negative. Between 12 June and 28 August 2009 , in the pre-epidemic phase, 18 contacts of confirmed cases, were also tested for pandemic influenza $A\left(H_{1} N_{1}\right) 2009$. Ten contacts who were asymptomatic tested positive for pandemic influenza 2009. Contacts

\section{TABLE 2}

Laboratory-confirmed cases of influenza A(H1N1)2009, and $\mathrm{A}(\mathrm{H} 1 \mathrm{~N} 1) 2009$ virus negative patients with influenzalike illness, by age group, Mohammed V Military Teaching Hospital, Rabat, Morocco, 12 June-24 December $2009(n=594)$

\begin{tabular}{|l|c|c|c|}
\hline $\begin{array}{l}\text { Age of patients } \\
\text { in years }\end{array}$ & $\begin{array}{c}\text { Number of } \\
\text { A(H1N1)2009- } \\
\text { negative cases }\end{array}$ & $\begin{array}{c}\text { Number of } \\
\text { A(H1N1)2009- } \\
\text { positive cases }\end{array}$ & Total (\%) \\
\hline 0 to 5 & 20 & 18 & $\mathbf{3 8 ( 6 )}$ \\
\hline >5 to 14 & 48 & 65 & $113(19)$ \\
\hline >14 to 27 & 82 & 72 & $154(26)$ \\
\hline >27 to 40 & 97 & 52 & $149(25)$ \\
\hline >40 to 50 & 72 & 28 & $100(17)$ \\
\hline$>50$ & 35 & 5 & $40(7)$ \\
\hline Total & 354 & 240 & $594(100)$ \\
\hline
\end{tabular}

presenting with ILI were considered as ILI patients for our analysis.

At the beginning of the outbreak, 27 confirmed cases required a few days of hospitalisation because they had identifiable underlying conditions. These included pregnancy $(n=13)$, asthma $(n=7)$, obesity $(n=2)$ and diabetes mellitus $(n=5)$. All these cases were put under supervision until their full recovery.

A rapid increase in the number of confirmed cases was observed with a peak in weeks 47 to 49 (16 November to 6 December 2009): 172 cases were detected during this time (Figure 1).

At the beginning of the study period, from 12 June to 28 August all cases were imported $(n=13,100 \%)$, seven from Spain, two from France, and one respective case from Italy, the Netherlands, Brazil and Canada. In the epidemic period, the proportion of cases with no travel history increased from mid-November 2009, to reach $92 \%(n=222)$ by 24 December.

Of the total confirmed cases of influenza $\mathrm{A}\left(\mathrm{H}_{1} \mathrm{~N}_{1}\right)_{2009}$ virus infection over the whole study period, 149 (62\%) were men (Table 1). There were no differences in the mean age of cases by sex (women: $24 \pm 14$ years, men: $22 \pm 14, p=0.57)$.

The ages of confirmed cases ranged between three months and 60 years, with a mean of 23 years (standard deviation: 14). The age followed a normal distribution according to the Kolmogorov-Smirnov test. A total of 207 (86\%) cases were aged 40 years old and younger and only 5 cases ( $2 \%$ ) were aged over 50 years. Compared to the reference group ( 40 years), the risk of infection was greater in those aged 14 years old and under (OR: 3.38; 95\% Cl: 1.99-5.73, p<0.001) and those aged from 14 to 27 years (OR: $2.62 ; 95 \% \mathrm{Cl}: 1.55-4.42$, p<0.05) (Table 2, Figure 2).

Table 2. Laboratory-confirmed cases of influenza $A\left(H_{1} N_{1}\right) 2009$, and $A\left(H_{1} N_{1}\right) 2009$ virus negative patients

\section{FIGURE 2}

Laboratory-confirmed cases of influenza A(H1N1)2009 by sex and age group, Mohammed V Military Teaching Hospital, Rabat, Morocco, 12 June-24 December 2009 $(\mathrm{n}=240)$

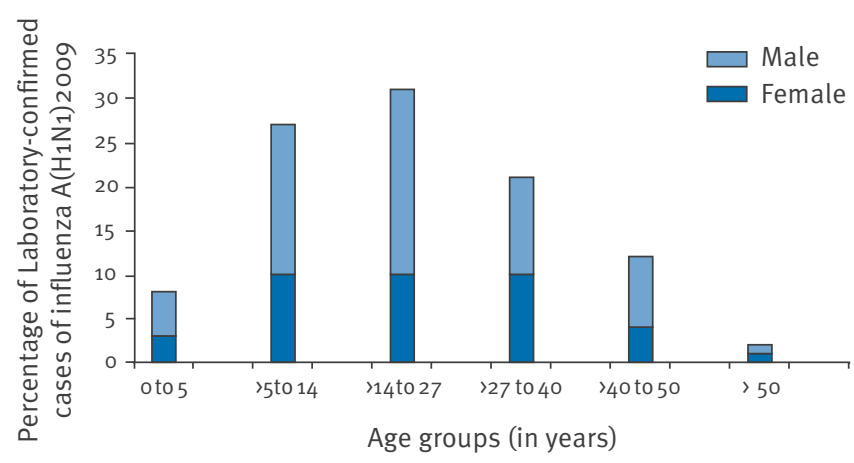


with influenza-like illness, by age group, Mohammed $\mathrm{V}$ Military Teaching Hospital, Rabat, Morocco, 12 June-24 December $2009(n=594)$

Fever, cough, headache, muscular pain and rhinorrhoea were the main symptoms: cough was the most common $(n=200,82 \%)$ followed by fever $(n=195,80 \%)$. The ORs were $4.2(95 \% \mathrm{Cl}: 2.51-7.04$, p<0.001) and 5.58 (95\% Cl: 3.43-9.09, p<0.001) for cough and fever respectively. Diarrhoea or vomiting was reported in 12 cases (5\%). None of the 240 cases developed any complications and there were no deaths during the study period. Variations of symptoms by age groups were not significant (Table 3).

A total of 238 (99\%) cases received antiviral treatment with neuraminidase inhibitors (oseltamivir) immediately after laboratory confirmation of the infection.

\section{Discussion}

Morocco was the first country in North Africa to report a laboratory-confirmed case of influenza $A\left(\mathrm{H}_{1} \mathrm{~N}_{1}\right) 2009$ virus infection. Here we present a study from Morocco, thereby contributing data from North Africa to the global data and adding to the overview of the $\mathrm{A}\left(\mathrm{H}_{1} \mathrm{~N}_{1}\right) 2009$ pandemic. The epidemic curve obtained for the hospital outpatients of this study was similar to the epidemic curve for the pandemic in Morocco [5]. In European countries, the pandemic started in weeks 30 to 32 , 2009, and the number of confirmed-cases peaked in weeks 48 and 49 followed by a decline in weeks five to six, $2010[9,10]$. In contrast, the pre-epidemic period in Morocco began on week 34, 2009. The first positive case that we observed in our study was imported as well as all cases reported every week until week 40 . This is in agreement with what was generally observed in Morocco where the first cases of $\mathrm{A}\left(\mathrm{H}_{1} \mathrm{~N}_{1}\right)_{2009}$ virus infections were detected among Moroccans returning from a travel to a country where the virus was circulating actively and also from Moroccans residing abroad visiting their country. It is noteworthy that out of the first 13 cases we observed in our study, 11 were imported from Europe. This may reflect the impact of the population flows between Europe and Morocco:
Almost 3.5 million Moroccan workers and their families live in Europe and return to Morocco for holidays every summer [11] and in addition approximately eight millions tourists from Europe, Asia and North America visit Morocco each year [11].

In weeks 41, 42, and 43, no confirmed case was reported. This can be explained by the fact that, by the end of summer holidays, there was a decline in arrivals of tourists and Moroccans who had spent their holidays abroad. Moreover, the measures taken for containment could also have contributed to the delay of the emergence of secondary cases until the week 44 marking the shift from imported to local cases. The peak of the epidemic was reported on week 49 and then the number of confirmed cases decreased from week 52 . This difference with European countries is probably due to the fact that the decline in temperatures settles earlier in Europe than in Morocco and lasts for a longer period.

The distribution of the 240 cases of laboratory-confirmed $A\left(\mathrm{H}_{1} \mathrm{~N}_{1}\right)_{2} 009$ virus infection by sex and age group was similar to that of cases observed in several European countries which may have a climate almost similar to that of Morocco like Spain [12] or with much cooler winters like Ireland [13]. There was an under-representation of infection in older people and the majority of cases were 40 years and under (86\%). It has been shown that schoolchildren play an important role in the spread of influenza $\mathrm{A}\left(\mathrm{H}_{1} \mathrm{~N}_{1}\right) 2009$ virus [12] and this predominance of infection in young people has been reported by other authors [15-16].

Moreover, several reports of the $\mathrm{A}\left(\mathrm{H}_{1} \mathrm{~N}_{1}\right)_{2009}$ pandemic showed that attack rates were higher in children younger than 15 years $[16,17]$. In addition, a report from Mexico noted that most cases occurred in people younger than 50 years, with $89 \%$ of cases of pneumonia [17] and $85 \%$ incidence of mortality due to $\mathrm{A}\left(\mathrm{H}_{1} \mathrm{~N}_{1}\right)_{2009}$ infection in this age group [18]. The lower frequency of influenza $A\left(\mathrm{H}_{1} \mathrm{~N}_{1}\right)_{2009}$ cases among those over 50 years of age is consistent with other investigations $[17,18,19]$. This can be explained by the fact that older people may have partial immunity from previous exposure to other influenza $A\left(\mathrm{H}_{1} \mathrm{~N}_{1}\right)$ strains [20] or that the

\section{TABLE 3}

Symptoms by age group of laboratory-confirmed cases of influenza A(H1N1)2009 virus infection, Mohammed V Military Teaching Hospital, Rabat, Morocco, 12 June-24 December 2009 ( $\mathrm{n}=240)$

\begin{tabular}{|c|c|c|c|c|c|c|c|c|}
\hline \multirow[b]{2}{*}{ Clinical symptoms } & \multirow[b]{2}{*}{ Total n (\%) } & \multicolumn{6}{|c|}{ Age of patients in years } & \multirow[b]{2}{*}{$\mathrm{p}$ value } \\
\hline & & $\begin{array}{l}\text { o to } 5 \\
\text { n (\%) }\end{array}$ & $\begin{array}{c}>5 \text { to } 14 \\
\text { n (\%) }\end{array}$ & $\begin{array}{c}>14 \text { to } 27 \\
\text { n (\%) }\end{array}$ & $\begin{array}{c}>27 \text { to } 40 \\
\text { n (\%) }\end{array}$ & $\begin{array}{c}>40 \text { to } 50 \\
n(\%)\end{array}$ & $\begin{array}{c}>50 \\
n(\%)\end{array}$ & \\
\hline Cough & $199(83)$ & $14(7)$ & $58(29)$ & $59(30)$ & $41(21)$ & $23(12)$ & $4(2)$ & 0.168 \\
\hline Fever & $193(80)$ & $15(8)$ & $56(29)$ & $57(30)$ & 37 (19) & $25(13)$ & $3(2)$ & 0.060 \\
\hline Muscular pain & $122(51)$ & $6(5)$ & $28(23)$ & $45(37)$ & $25(20)$ & $16(13)$ & $2(2)$ & 0.210 \\
\hline Headache & $54(23)$ & $2(4)$ & $8(15)$ & $27(50)$ & $9(17)$ & $8(15)$ & 0 & 0.239 \\
\hline Rhinorrhoea & $85(35)$ & $3(4)$ & $18(21)$ & $31(36)$ & $20(24)$ & $13(15)$ & 0 & 0.083 \\
\hline Dyspnoea & $5(2)$ & 0 & $1(20)$ & $2(40)$ & $1(20)$ & $1(20)$ & 0 & 0.564 \\
\hline Diarrhoea, vomiting & $12(5)$ & $2(17)$ & $2(17)$ & $4(33)$ & o & 4(33) & 0 & 0.894 \\
\hline
\end{tabular}


influenza $\mathrm{A}\left(\mathrm{H}_{1} \mathrm{~N}_{1}\right)_{2009}$ virus had not been widely introduced in this subpopulation.

The clinical manifestation of influenza $A\left(\mathrm{H}_{1} \mathrm{~N}_{1}\right) 2009$ virus infection in our investigation was similar to that observed for seasonal influenza $[14,21,22]$. All cases presented predominantly mild and self-limiting illness, with cough and fever being the most common symptoms. The ORs for fever and cough (3.38; 2.62 respectively) were consistent with a literature review by Petrosillo et al. with descriptions of $A\left(\mathrm{H}_{1} \mathrm{~N}_{1}\right) 2009$ cases across the world [23]. According to this study, $A\left(\mathrm{H}_{1} \mathrm{~N}_{1}\right)_{2009}$ patients complained mostly of the classical influenza symptoms. In the review from Petrosillo et al., fever was reported by a median of $87 \%$ (62-100\%) of cases, cough by $82.5 \%$ (59-100\%), sore throat by $57 \%(2-82 \%)$, diarrhoea by $13.5 \%$ (2-50\%), and vomiting by $12.5 \%(2-50 \%)$. Other reported symptoms included myalgia, arthralgia, nasal-congestion headache, anorexia, nausea and conjunctivitis.

In our study, some cases required a few days of hospitalisation at the beginning of the outbreak because they had identifiable underlying conditions (such as pregnancy, asthma, obesity and diabetes mellitus). It was a precautionary measure given that during this period the pathogenicity of the $A\left(\mathrm{H}_{1} \mathrm{~N}_{1}\right) 2009$ virus was still poorly known. All these cases evolved favorably under treatment.

Almost all of the confirmed cases (98\%) received early treatment (24 to 48 hours after onset of symptoms) with neuraminidase inhibitors, which may have had a favourable impact on the clinical expression of the infection. Indeed, most of them presented with mild illness and made good progress under specific antiviral treatment and no deaths were recorded. However, in another report from Morocco, the mortality rate was $3.5 \%$. This difference may be explained by the fact that this study included hospitalised cases and severe infections [24] in contrast to the outpatients in this study.

The limitations of our study stem from the fact that it is derived from only one hospital. Also because of the workload of the clinicians during the pandemic period, the questionnaires were not always properly informed, in particular information on co-morbidities. Therefore some data were missing and not exploitable.

The study nevertheless contributed to the epidemiological surveillance of $\mathrm{A}\left(\mathrm{H}_{1} \mathrm{~N}_{1}\right)_{2} 009$ virus infections (number of cases, deaths, changes over time) during the pandemic and allowed to enrich national and international databases.

\section{Acknowledgements}

The authors thank Dr Abdellatif Allami for his help in carrying out statistical analysis in this study.
References

1. Centers for Disease Control and Prevention (CDC). Update: swine influenza $A\left(\mathrm{H}_{1} \mathrm{~N}_{1}\right)$ infections-California and Texas, April 2009; MMWR Morb Mortal Wkly Rep. 2009;58(16):435-7.

2. World Health Organization (WHO). Pandemic $\left(\mathrm{H}_{1} \mathrm{~N}_{1}\right)$ - update 64. 04 September 2009. WHO; 2011. Available from: http:// www.who.int/csr/don/2009_09_04/en/index.html

3. World Health Organization (WHO). World now at the start of 2009 influenza pandemic. Geneva: WHO; Jun2009. Available from: http://www.who.int/mediacentre/news/ statements/2009/h1n1_pandemic_phase6_20090611/en/ index.html

4. Lematin.ma [Internet]. Grippe $\mathrm{A} \mathrm{H}_{1} \mathrm{~N}_{1}$. Premier cas enregistré au Maroc [A H1 $\mathrm{N}_{1}$ influenza. First case identified in Morocco]. Lematin.ma. 12 Jun 2009. French. Available from: http://www. lematin.ma/actualite/express/Article.asp?id=114909

5. Moroccan Ministry of Health. Surveillance de la grippe clinique Maroc, Saison $2009-2010$ [Surveillance of clinical influenza, Morocco, season 2009-2010]. [Accessed 09 June 2011]. French. Available from: http://srvweb.sante.gov.ma/Publishinglmages/ GrippSem9-2010.pdf

6. Steffen C, Diop OM, Gessner BD, Hacen MM, Hassar M, Katz $M A$ et al, Afriflu--international conference on influenza disease burden in Africa, 1-2 June 2010, Marrakech, Morocco. Vaccine. 2011;29(3):363-9.

7. Schoub BD. Surveillance and management of influenza on the African continent. Expert Rev Respir Med. 2010;4(2):167-9.

8. World Health Organization (WHO). Guidance on regulations for the Transport of Infectious Substances. WHO; Sep 2005. Available from: http://www.who.int/csr/resources/ publications/biosafety/WHO_CDS_CSR_LYO_2005_22r\%20. pdf

9. Institut de veille sanitaire (InVS). Grippe: Bulletin hebdomadaire de surveillance de la grippe saisonnière Saison 2010 - 2011 [Influenza: Weekly bulletin monitoring seasonal influenza - $2010-2011$ saeson]. InVS. [Accessed 27 May 2011]. French. Available from: http://www.invs. sante.fr/display/?doc=surveillance/grippe_dossier/points_ actu_2010_11.htm

10. Devaux I, Kreidl P, Penttinen P, Salminen M, Zucs P, Ammon A. Initial surveillance of 2009 influenza $A\left(\mathrm{H}_{1} \mathrm{~N}_{1}\right)$ pandemic in the European Union and European Economic Area, AprilSeptember 2009. Euro Surveill. 2010;15(49): pii=19740. Available from: http://www.eurosurveillance.org/ViewArticle. aspx?Articleld $=19740$

11. Moroccan ministry of tourism. [Accessed 09 Jun 2011]. Available from: http://www.tourisme.gov.ma/francais/5Tourisme-chiffres/ArriveeTouristes.htm

12. Surveillance Group for New Influenza $A\left(\mathrm{H}_{1} \mathrm{~N}_{1}\right)$ Virus Investigation and Control in Spain. New influenzaA(H1N1) virus infections in Spain, April-May 2009 Euro Surveill. 2009;14(19). pii: 19209. Available from: http://www.eurosurveillance.org/ ViewArticle.aspx?Articleld=19209.

13. G Cullen, J Martin, J O’Donnell, M Boland, M Canny, E Keane, A McNamara, A O'Hora, M Fitzgerald, S Jackson, D Igoe, D O'Flanagan. Surveillance of the first 205 confirmed hospitalised cases of pandemic $\mathrm{H}_{1} \mathrm{~N}_{1}$ influenza in Ireland, 28 April-3 October 2009. Euro Surveill. 2009;14(44):pii=19389. Available from: http://www.eurosurveillance.org/ViewArticle. aspx? Articleld=19389

14. Shimada T, Gu Y, Kamiya H, Komiya N, Odaira F, Sunagawa T, et al. Epidemiology of influenza $A\left(\mathrm{H}_{1} \mathrm{~N}_{1}\right) v$ virus infection in Japan, May-June 2009. Euro Surveill. 2009;14(24):pii=19244. Availablefrom:http://www.eurosurveillance.org/ViewArticle. aspx?Articleld $=19244$

15. Cutler J, Schleihauf E, Hatchette TF, Billard B, Watson-Creed G, Davidson R, et al. Investigation of the first cases of human-tohuman infection with the new swine-origin influenza $A\left(\mathrm{H}_{1} \mathrm{~N}_{1}\right)$ virus in Canada. CMAJ. 2009;181(3-4):159-63.

16. Fraser C, Donnelly CA, Cauchemez S, Hanage WP, Van Kerkhove MD, Hollingsworth TD, et al. Pandemic potential of a strain of influenza $A\left(\mathrm{H}_{1} \mathrm{~N}_{1}\right)$ : early findings. Science. 2009;324(5934):1557-61.

17. Perez-Padilla R, de la Rosa-Zamboni D, Ponce de Leon S, Hernandez M, Quiñones-Falconi F, Bautista E, et al. Pneumonia and respiratory failure from swine-origin influenza $A\left(\mathrm{H}_{1} \mathrm{~N}_{1}\right)$ in Mexico. N Engl J Med. 2009;361(7):680-9.

18. Chowell G, Bertozzi SM, Colchero MA, Lopez-Gatell H, AlpucheAranda $C$, Hernandez $M$, et al. Severe respiratory disease concurrent with the circulation of $\mathrm{H}_{1} \mathrm{~N}_{1}$ influenza. N Engl J Med. 2009;361(7): 674-79.

19. Human infection with new influenza $A\left(\mathrm{H}_{1} \mathrm{~N}_{1}\right)$ virus: Mexico, update, March-May 2009. Wkly Epidemiol Rec. 2009;84(23):213-9. 
20. Ikonen N, Strengell M, Kinnunen L, Osterlund P, Pirhonen J, Broman $M$, et al. High frequency of cross-reacting antibodies against 2009 pandemic influenza $A\left(\mathrm{H}_{1} \mathrm{~N}_{1}\right)$ virus among the elderly in Finland. Euro Surveill. 2010 Feb 4;15(5). pii: 19478. Available from: http://www.eurosurveillance.org/ViewArticle. aspx?Articleld $=19478$

21. Libster R, Bugna J, Coviello S, Hijano DR, Dunaiewsky M, Reynoso N, et al. Pediatric hospitalizations associated with 2009 pandemic influenza A (H1N1) in Argentina. N Engl J Med. 2010;362(1):45-55.

22. Cao B, Li XW, Mao Y, Wang J, Lu HZ, Chen YS, et al.

Clinical features of the initial cases of 2009 pandemic influenza $A\left(\mathrm{H}_{1} \mathrm{~N}_{1}\right)$ virus infection in China. $\mathrm{N}$ Engl J Med 2009;361(26):2507-17.

23. Petrosillo N, Di Bella S, Drapeau C M, Grilli E. The novel influenza $A\left(\mathrm{H}_{1} \mathrm{~N}_{1}\right)$ virus pandemic: An update. Ann Thorac Med. 2009;4(4):163-172.

24. Louriz M, Mahraoui C, Azzouzi A, El Fassy Fihri MT, Zeggwagh AA, Abidi K,et al. Clinical features of the initial cases of 2009 pandemic influenza $A\left(\mathrm{H}_{1} \mathrm{~N}_{1}\right)$ virus infection in an university hospital of Morocco. Int Arch Med. 2010;3:26. 